\title{
The role of companion animals in the environmental circulation of tick-borne bacterial pathogens
}

\author{
Bogumiła Skotarczak ${ }^{1, A-F}$ \\ ${ }^{1}$ Department of Genetics, Faculty of Biology, University of Szczecin, Poland \\ A - Research concept and design, B - Collection and/or assembly of data, C - Data analysis and interpretation, \\ $D$ - Writing the article, E-Critical revision of the article, $F$ - Final approval of article
}

Skotarczak B. The role of companion animals in the environmental circulation of tick-borne bacterial pathogens. Ann Agric Environ Med. 2018; 25(3): 473-480. doi: 10.26444/aaem/93381

\begin{abstract}
Ticks are known as vectors of a wide range of pathogens of medical and veterinary importance; some of them of zoonotic concern constitute a hazard for the emergence of tick-borne diseases shared between humans and domestic animals and becoming a part of the 'One Health' concept. Canine and feline tick-borne diseases have emerged in recent years, performing an extensive geographic distribution and enlarged global prevalence. The present review focuses on the recent epidemiological studies on the emergence of tick-borne bacterial pathogens in dogs and cats, and the discussion whether pet ownership increases the risk of tick-borne diseases. A lot of data provide confirmation that dogs and cats themselves may substantially contribute to the circulation of the ticks and tick-borne bacterial pathogens in the environment. Molecular diagnostics of tick-borne pathogens infections generates a lot of problems like the choice of molecular methods and molecular markers for the detection of bacterial genomic DNA, but play an important role in the diagnosis of infections. The study provides some insight into molecular diagnostic techniques and new potentially recognized bacterial pathogens of this group. Protecting human and companion animal health from vector-borne infections requires controlling vector populations, containing development of novel, practicable strategies that will limit vectors and transmission of vectorborne disease pathogens.
\end{abstract}

Key words:

'One Health' concept, ticks, Ixodes ricinus, cats, dogs, bacterial tick-borne diseases, epidemiology, molecular tools, risk for pet owners

\section{INTRODUCTION}

In recent decades, the importance of vector-borne diseases in both human and veterinary medicine has spread dramatically. The spread of arthropod vectors to new areas, geographic wide-extent of pathogens, and recognition of new pathogens have all contributed to the hightened importance and attentiveness of vector-borne infections. In recent years, the frequency of some vector-borne diseases has been increasing partly due to climatic changes, especially global warming, which can also affect arthropod vector concentration, and has a direct influence on the abundance, geographical distribution and vectorial ability of arthropod vectors [1]. Additionally, other factors have been connected to the changing epidemiology of vector-borne diseases, like many ways of transport which have strongly increased, with intense animals production and also sport and companion animals. These movements provide very good conditions for the circulation of pathogens. The increasing mobility of the human populations and their companion animals due to the recreation model of spending time and travelling to distant places, support pathogen and vector exchanges $[1,2]$.

The vector-borne agents comprise a group of globallydistributed and spreading pathogens causing several zoonotic diseases transmitted by the bite of hematophagous arthropods, mainly ticks and mosquitoes. The most common

Address for correspondence: Bogumiła Skotarczak Department of Genetics, Faculty of Biology, University of Szczecin, Felczaka 3c, 71-412 Szczecin, Poland e-mail: genetyka@univ.szczecin.pl

Received: 05.04.2018; accepted: 13.07.2018; first published: 23.08.2018 tick in northern Europe is Ixodes ricinus, which is known as a vector of a wide range of pathogens of medical and veterinary importance, such as viruses, bacteria and protozoa. A wide spectrum of tick-borne pathogens identified in many studies, constitute a hazard for the emergence of tick-borne diseases in domestic animals and in humans [3-6]. Dogs and cats may play a significant role in the transmission cycles of many agents of vector-borne diseases by serving as amplifying hosts $[5,6]$. Many of these pet vector-borne pathogens can also affect humans due to their zoonotic potential. When molecular diagnostic techniques become available, more sensitive and specific differentiation of tick-borne agents will be possible, as tick-borne diseases are recognized as an emerging infectious threat not only to humans and pets, but also because of the public health importance of many of these infectious disease agents.

\section{OBJECTIVE}

The review focuses on the role of dogs and cats as companion animals in the environmental circulation of tick-borne bacterial pathogens and discusses whether pet ownership increases the risk of tick-borne diseases. Some insight is provided into molecular diagnostic techniques and new potentially recognized bacterial pathogens of this group.

'One Health' in companion animal vector-borne diseases. Canine vector-borne diseases shared between humans and dogs, point evidently to the obligation to join under the 'One 
Health' concept in all aspects, from epidemiology, clinic, diagnostic, therapy and prevention [7], and as described Mencke [8], are a perfect example of the importance of interdisciplinary cooperation.

The international importance of the 'One Health' concept of co-ordinated activity of those involved in human and animal health is a modern personification of a long tradition of comparative medicine, with an explosion of knowledge in the area of infectious disease research [9]. The modern 'One Health' pays the attention to zoonotic pathogens emerging from wildlife and production animal species, and is now considering the role of small companion animals, and especially for the vector-borne infectious diseases shared by man, dogs and cats. The most important of these are bacterial diseases: borreliosis, ehrlichiosis, rickettsiosis, anaplasmosis, bartonellosis, and protozoal leishmaniosis [10]. The impact of environmental changes (e.g. climate change, deforestation and urbanization) and lifestyle changes, including the increase in global human and animal movement, has also become a part of the 'One Health' concept [11]. Therefore, it seems that only a multidisciplinary 'OneHealth' approach, integrating research outputs of experts from different disciplines, its veterinarians, molecular biologists, epidemiologists, physicians, and sociologists, etc., collectively with appropriate outreach can successfully make urban and peri-urban areas free from infection by tick-borne pathogens $[8,12]$. The cited authors noticed that controlling canine vector-borne diseases obviously needs 'One Health' tactic and proper environmental control of arthropod vectored pathogens, based on ectoparasiticides with repellent properties to stop blood sucking with haematophagous, to block the interaction between the arthropod vector and the host which may conduct infections.

Tick-borne diseases in urban and peri-urban areas mean a rising risk for public and animal health in Europe. Certain tick-borne infections have recently strayed, emerging in new regions or re-emerging within endemic locations and creating increased alarm for public health, food security, and biodiversity protection [13]. Evidently, global warming changes the spread of tick-borne diseases, but not only climate conditions determine the geographical distribution of tick species, their population densities and dynamics, the possibility of their infection with pathogens for humans and animals, and finally the frequency of contacts of humans and domestic animals with infected ticks [12, 13]. Deforestation and reforestation are known as the factors which have a big influence on the transformation of biotopes, thus it affects tick host accumulations as well as tick infection rates [14]. Ixodes ricinus is mainly associated with mixed forests, but recently, abundant tick populations have been detected in European urban green areas, which are of public health importance due to the exposure of humans and companion animals to potentially infected ticks $[15,16]$. In urban habitats, small and medium-sized mammals, birds, dogs and cats as companion animals, rarely larger mammals (roe deer and wild boar) play a role in vector ecology, in the maintenance of tick populations and as reservoirs of tick-borne pathogens. As it is known, urbanization, due to the restriction of natural areas, dramatically change the composition of wildlife species and affect the associated tick populations. In European cities, public parks, gardens, periurban areas, and cemeteries are principally the important places where humans and companion animals can encounter potentially infected questing ticks [17]. A Polish study evaluating the prevalence of A. phagocytophilum, Neoerlichia micurensis and Rickettsia spp. in ticks collected from cats and dogs in an urban area (Wroclaw agglomeration, southwestern Poland) demonstrated the high tick infestation rates and high prevalence of pathogens found in these ticks [18]. The authors concluded that dogs and cats themselves may significantly contribute to the circulation not only of the ticks but also pathogens in urban area.

Bacterial tick-borne diseases in dogs and cats. The major tick-borne infectious diseases are shared by man, dogs and cats. Among the bacterial diseases transmitted by I. ricinus the most significant are borreliosis, anaplasmosis, ehrlichiosis, and rickettsiosis.

Lyme borreliosis (LB) is known as one of the main emerging tick-borne disease in temperate regions in Europe and North America [19]. In Europe, the most recent cases of canine borreliosis have been noted in almost all countries [20-22], including Poland [23-27].

In recent years, reported cases of human borreliosis in Poland (according to the National Institute of Public Health) have increased more than 4 times, from 22.8 per 100,000 in 2012 to 55.2 per 100,000 in 2016 ; in 2015 , there were 13,625 reported cases and 21,200 in 2016, but with considerable under-reporting, the number of cases was probably several times higher. The highest number of human cases of borreliosis in Poland in 2016 was registered in the Silesian Province, but the highest incidence rate was in Podlaskie Province with 134.9 per 100,000 people (Polish Institute of Hygiene).

Borrelia burgdorferi sensu lato $(\boldsymbol{B b s l})$ is a group of spirochete bacteria species, some of which cause LB in humans and dogs. To date, it has been supposed that in European dogs, the same as in humans, three pathogenic species of Bbsl: B. afzelii, B. garinii and B. burgdorferi sensu stricto are the most common European circulating genospecies, and are the etiological agents of LB [26, 28-31]. In The Netherlands, Belgium and Luxembourg, B. valaisiana has been also found [32-34], and in Polish and Belgian studies, B. valaisiana, $B$. spielmanii and $B$. lusitaniae $[4,35]$ were detected. Thus, dogs as well as humans are hosts for many species of Bbsl, because the borreliacidal ability of serum of dogs and humans is evident only in certain genospecies of Bbsl [36]. Thus, both dogs and humans harbour more species than wild animal species, which generate phylogenetically older Bbsl species-host systems, and these animals may act even as noncompetent reservoir hosts [36]. Apart from many genospecies of $B b s l$, dogs harbour other tick-borne agents and dual or triple infections may occur.

Anaplasma spp. (Rickettsiales, Anaplasmataceae) are intracellular bacteria and two species infect dogs: Anaplasma phagocytophilum, the causative agent of granulocytic anaplasmosis, and A. platys, causing thrombocytic anaplasmosis. The latter species has a worldwide distribution, with descriptions of infection from South and North America, Australia, Asia and Africa, and is associated with the Rhipicephalus sanguineus tick. A. phagocytophilum occurs in the northern hemisphere, and it is vectored by hard ticks of the Ixodes ricinus, among them, the sheep tick 
I. ricinus in Europe. A. phagocytophilum has been detected across Europe, with varying prevalence in ticks, ranging from $1.7 \%$ in north-eastern Slovakia [37], $4.1 \%$ in Germany [38], $10.4 \%$ in central Italy [39] to $20.5 \%$ in Spain [40]. In Poland, the pathogen $A$. phagocytophilum is reported to occur in its vector $I$. ricinus in numerous studies and the prevalence in ticks has been ranging from $2.9 \%$ in the central region [41] to $4.5 \%$ in the north-west [42]. In south-western Poland, 2 species of ticks, $I$. ricinus and $I$. hexagonus collected from dogs and cats were infected in $14.4 \%$ [18]. In man (mainly forest workers as a particularly tick-exposed group within the population), antibodies against $A$. phagocytophilum have also been detected, e.g., in $17.7 \%$ in north-eastern Poland [43] and $19.8 \%$ in the eastern region [44].

In a few studies, blood samples from dogs have been screened with molecular methods with the results of $2 / 192$ dogs being DNA positive for $A$. phagocytophilum [45], 0.5\% of 408 dogs [27], and 14\% of dogs suspected of having Lyme disease being positive for A. phagocytophilum [46], and 1/79 dogs being positive in a group of apparently healthy sled dogs [47]. Italian research showed A. phagocytophium DNA in $7.5 \%$ of 50 dogs [48]. Polish research [26] showed the co-occurrence of $A$. phagocytophilum DNA in the blood of dog undergoing treatment for borreliosis. The same dog also proved positive for the presence of borrelia DNA. Cooccurrence of both pathogens did not disturb the clinical picture of borreliosis, and the administered treatment was also effective for the mixed infection.

Seroprevalence rates in dogs from European countries are generally high, i.e. $8.76 \%$ in central Italy [49], 10.6\% of cats in Romania and Hungary [50], and $13.5 \%$ of cats in Portugal [51]. In a large study in Poland, 3,094 serum samples were taken from dogs throughout all 16 Polish provinces and $12.3 \%$ and $3.75 \%$ of the dogs were positive for A. phagocytophilum and $B$. burgdorferi s.l., respectively, and co-infections with both pathogens were recorded in $1.71 \%$ of all examined dogs [52].

In addition to the occurrence of the pathogen in dogs, it has also been reported in diverse forms of wildlife in Poland, e.g., roe deer [53] and wild cervids [54]. Even though this aspect is not examined very often within the canine or feline population, there is a clear risk of infection by frequently reported A. phagocytophilum-positive I. ricinus ticks in Poland.

Neoehrlichia mikurensis (NM, formerly Candidatus Neoerlichia micurensis, CNM), another member of Anaplasmataceae (Rickettsiales), reported for ticks from several parts of Europe $[38,55]$. Severe cases have been reported mainly in immunocompromised human patients $[56,57]$. The causative agent, the intracellular bacterium NM, is considered an emerging tick-borne pathogen in Europe where it is transmitted by $I$. ricinus acting as a vector for numerous zoonotic tick-borne pathogens [58]. NM has been identified as one of the most prevalent microorganism in I. ricinus, indicating frequent exposure of animals to this potentially pathogenic species [59]. Dogs also appear to be infected by NM [60]. In a Croatian retrospective study with archival tissues from 19 dogs which died from haemolytic anaemia, NM was detected and confirmed by sequencing in a 3.5-months-old dog [61]. This finding is probably the first case in which NM may have been pathogenic for younger dogs. There is no evidence of pathogenicity in other domestic animal species. Recently, the presence of NM in samples of dogs' blood was detected in Brandenburg, northern Germany; in 3 from 1,023 samples [62], but for now, the role of NM in disease development in companion animals remains unclear yet [56].

Cats also are hosts for I. ricinus ticks and feline vectorborne diseases have emerged in recent years, giving a broader geographic distribution and increased worldwide occurrence [5]. Domestic cats play a crucial role in the transmission cycles of some tick-borne agents by existence as reservoirs and amplifying hosts, the conditions that the 'One Health' concept requires [9]. Kaplan et al. [10] have recently notified that the detection of vector-borne pathogens is very challenging as some of them occur in healthy cats and the clinical signs are unspecific. PCR-based protocols applied to vector-borne pathogens are very effective for detecting and typify infecting pathogens, for monitoring treatment after chemotherapy, and for assessing the role that subclinicallyinfected cats can play in the spread of infections [10].

Generally, in the scientific literature there are only few reports on LB in cats. The explanation might be a different tick infestation in cats compared to dogs, a low exposure to tick-borne infections, or a low alertness of veterinarians for tick-borne diseases in feline patients [63]. The aim of the study by Pantchev et al. [63] was to determine the proportion of antibodies against $B b s \mathrm{l}$ in feline sera and to compare the significance of feline and canine borreliosis. Specific antibodies against the C6-peptide of Bbsl in cats were detected by a test based on an enzyme immunoassay technique. The proportion of Borrelia antibody-positive cat sera was significantly lower than that determined for dogs during the same time period and residing in the same regions. All antibody positive cats came from countries endemic for LB (Germany, Sweden and Belgium), and all positive cats (except one) presented clinical signs. Obtained data revealed that diagnosis of 'feline LB' is rare in cats, but LB should be considered in cats with compatible clinical signs (leg lameness, and to a lesser extent, neurological signs) when other differential diagnoses have been ruled out.

The molecular detection and species identification of feline vector-borne bacteria and protozoa with veterinary and zoonotic importance, and evaluation of associated risk agents in cats, were the aims of the study of Maia et al. in Portugal [5]. 649 cats with clinical signs compatible with vector- borne diseases, from veterinary medical centres and animal shelters were examined. Anaplasma spp./Ehrlichia spp., Babesia spp., Bartonella spp., B. burgdorferi sensu lato, Hepatozoon spp. and Leishmania spp. infections were assessed by PCR in blood samples. $29.9 \%$ of the cats were PCR-positive for at least one of the tested genera, and $5.15 \%$ cats were positive to $2-3$ of the genera; the most common were protozoa (9.9-5.4\%) then Anaplasma spp./Ehrlichia spp. (5.4\%), Bartonella spp. $(2.9 \%)$ and B. burgdorferi s.l. complex (2.2\%). In conclusion, the authors noted that the occurrence of feline tick-borne agents in southern Portugal, some of a zoonotic character, shows the need of attention of the veterinarians, owners and public health authorities for the risk of infection, and the control quantity should be implemented to prevent the infection of cats, other vertebrate hosts and people.

In the north-eastern part of the USA, where I. scapularis is a main tick-vector, the seroprevalence of antibodies against B. burgdorferi and A. phagocytophilum in cats was examined by Magnarelli et al. [64] to determine whether cats develop serum antibodies against antigens of $B$. burgdorferi and 
A. phagocytophilum, and whether coinfection with the 2 organisms occurs. Serum samples from 84 healthy cats and 9 cats with lameness, fever, anorexia, or fatigue serum antibodies against 2 pathogens, were measured with an ELISA incorporating with Western blot analysis, or indirect fluorescent antibody (IFA) staining. ELISA results indicated that $47 \%$ sera contained antibodies against B. burgdorferi antigens, and seropositivity rates of $30 \%$ and $38 \%$ were detected for antibodies against A phagocytophilum via IFA and ELISA testing, respectively. $16 \%$ of sera had antibodies against both pathogens. The authors concluded that cats living in areas infested by I. scapularis ticks are exposed to B. burgdorferi and A. phagocytophilum and, in some cases, may be coinfected; nevertheless, most cats appeared to be healthy. In the opinion of Pennisi et al. [65], A. phagocytophilum is the most important feline pathogen among rickettsial organisms, and coinfections may occur. However, on the pathogenesis of these agents in cats, little information is available. Clinical signs are usually reported soon after tick infestation and are generally non-specific, involving fever, anorexia and lethargy and joint pain may occur. Because some rickettsial species are of zoonotic concern, direct contact with cat saliva should be avoided because of potential contamination by Rickettsia felis, for example. Infected cats are 'sentinels' of the occurrence of rickettsial pathogens in ticks and fleas in a given geographical zone, and the authors concluded that they signal a risk for people exposed to vectors $[65,66]$.

Molecular diagnostics. Unlike in the case of human infection, a typical case Lyme disease in dogs is not easy to document, mainly because many of the animals exposed to B. burgdorferi do not develop clinical abnormalities [67, $68]$. Nevertheless, the diagnostics of Bbsl infections should be based mainly on clinical symptoms and an assessment of the risk of exposure to infected ticks, combined with diagnostic tests, including the assessment of Borrelia spp. antibodies of IgM and IgG class. The common diagnostic tests for Borrelia spp. are divided into 2 different groups. The first one includes indirect tests, which make it possible to assess the contact of an individual with the pathogen (serum antibodies), and the second group, called direct tests, are able to detect the pathogen in the clinical material (culture collection, microscopic methods, PCR and realtime PCR). However, lack of standardization of PCR for the identification of Borrelia spirochaetes makes it impossible to compare the reports on this subject. PCR detection of $B b s l$ uses various molecular markers, i.e. DNA sequences located in the bacterial chromosome and in plasmids. As many studies have shown, some markers, as well as PCR protocols, are useful for genospecies differentiation of $\mathrm{Bbsl}$ and phylogenetical analysis from the genetic material of ticks, others for clinical diagnostics. The spirochete expresses OspA, but not OspC, when is present in the midgut of unfed ticks, but during a tick's blood meal some spirochetes stop expressing OspA and express OspC instead [69]. Some genes of $B b s l$ are expressed only in a mammalian host or have significantly upregulated expression in that environment, for example, VlsE, DbpA, BBK32, Erp, and Mlp proteins. For these reasons the detection of bacteria genomic DNA may play an important role in the diagnosis of Borrelia infections [70-72].

The collection and analysis of questing ticks, and investigation of host-associated ticks for the occurrence of pathogens is a valuable method for providing insight into the transmission patterns of tick-borne diseases [73, 74]. For tick samples, nested-PCR or PCR-RFLP targeting the flagellin gene $(f l a B)$, the intergenic spacer region (IGS) located between $5 \mathrm{~S}$ and $23 \mathrm{~S}$ rRNA, and the $g l p Q$ gene, as well as conventional PCR targeting the 16S rRNA, are often used for Borrelia DNA detection [75, 76]. Another study [77] revealed that the High-Resolution DNA Melting method with the groEL gene as marker is very useful for environmental samples. It enables identification of 8 Borrelia species, including $B$. miyamotoi from the relapsing fever borreliae group, and 7 from the B. burgdorferi s.l. complex (B. garinii, B. afzelii, B. burgdorferi s.s., B. valaisiana, B. lusitaniae, $B$. bissetii, B. spielmanii) in questing $I$. ricinus. The study by Dunaj et al. [78] and Jahfari et al. [79] demonstrated that RLB (Reverse Line Blot Hybridization) might be easily used in Borrelia DNA detection with genospecies-identification occurring in $I$. ricinus ticks. The real-time PCR for blood samples would be more useful [72].

It is believed that tick-based investigation is essential for monitoring human and/or animal disease emergence. Dogs can be used to deliver blood samples for serological surveys; however, there is an alternative method when pets are used as deliverers of tick samples for PCR analysis for the detection of the pathogen. In the USA, there is the evaluation of dogs as sentinel species for emergence of Lyme disease in areas with ticks infestation. This is very useful because by removing ticks from dogs for identification and pathogen testing, veterinarians can play an important role in early detection in areas with increasing risk of Lyme disease [80]. In conventional PCR assay, the limited number of different targets is used, usually the pathogens target is known to be vectored by certain tick species collected at particular sites [81]. The study of Michelet et al. [59] demonstrates the utility of a fast tool that allows for the comprehensive testing of high numbers of tick-borne pathogens in ticks. In this study, a method using multiple primers/probe sets was employed, in order to achieve high-throughput detection of tick-borne pathogens, which permitted the simultaneous detection of 25 bacterial and 12 parasitic species. Additionally, it allowed for the discovery of rare pathogens, such as Bartonella henselae. The study was conducted on the DNA samples of I. ricinus nymphs collected from vegetation from 3 European countries.

The aim of Jahfari et al. [79] was to detect the nucleic acid of specific pathogens in human blood through amplification with PCR and real-time PCR, and in ticks, using the RLB technique to detect infection by most of tick-borne pathogens. In comparison to the DNA amplification with PCR, available serological tests generally have a low specificity and sensitivity, mainly during the early stage of the infection. In addition, the authors noticed, although culturing is considered the most reliable method in demonstrating the presence of bacteria, it is time consuming. The limitations of this methodology are well known; therefore, the interpretation of these results should be made with caution. Also, it should be noted that the absence of DNA of a pathogen cannot be interpreted as the absence of the infectious agent. Cerar et al. [82] and Elfving et al. [83] mentioned that besides the limits of PCR-based methods, the time of sample collection after a tick bite and beginning of an antibiotic treatment, or the tissue tropism of the pathogen, strongly affect the ability of pathogen detection. In a study by Jahfari et al. [79], only in one of the 291 patients 
with an erythema migrans - caused by B. burgdorferi s.l. - the DNA of this pathogen was detected in blood, which confirms that the chance of detecting B. burgdorferi s. l. DNA in blood samples of confirmed Lyme borreliosis patients is very low. Neither Rickettsia helvetica nor R. monacensis was detected in 626 blood samples, whereas recent molecular evidence for their presence was found in the cerebrospinal fluid of neuroborreliosis patients, and in a skin sample of an EM patient $[84,85]$. Bil-Lula et al. [72] have noted that the real-time PCR assay seems to be very useful in testing blood sampled patients, first of all in the early stage of the disease, before an antibody response develops, and in cases where the patient does not have classic symptoms.

Canine borreliosis occurs most often in the articular form, affecting joints of limbs, usually the wrist or instep $[86,87]$. One or 2 joints become swollen and the inguinaland prescapular lymph nodes become enlarged. The associated symptoms are: 'malaise', expressed in elevated body temperature, loss of appetite, fatigue, and lameness in subsequent dys. Dogs suffering from borreliosis rarely develop myocarditis, although the older ones develop the renal form of this disease $[86,87]$. In addition, co-infections with 2 or more pathogens enhance diagnostic difficulties.

Molecular methods are useful for disentangling infections and accurately describing the prevalence and geographical distribution of tick-borne diseases, or in establishing the best strategies for treatment and control. Molecular diagnostics of tick-borne pathogens infections generate a lot of problems in the choice of molecular methods or molecular markers for the detection of bacterial genomic DNA.

For the detection of Rickettsia spp., a conventional PCR or a real-time PCR targeting the gltA genome region is used $[18,88,89]$. A real-time PCR targeting $m s p 2$ gene fragment is performing to detect $A$. phagocytophilum $[89,90]$. In order to detect Neoehrlichia mikurensis, a real-time PCR targeting the partial groEL gene (99 bp) is used [91, 92].

Has pet ownership increased the risk for tick encounters and tick-borne diseases? Dogs and cats live in the close vicinity of their owners and can act as direct sentinels for the infection of humans [80]. Pet dogs can be a very sensitive indication of infection risk and give a good signal of the exposure of their owners to infected ticks, because they largely share the same environment and visit the same outdoor areas $[93,94]$. Many authors from many parts of the world have shown that the rate of B. burgdorferi infection in humans and dogs depends on the intensity of occurrence of ticks, associated with the geographic locality of their biotope, and indicates the point of risk for humans and dogs [95]. Dogs living in tick-infested areas, in which cases of human LB have also been noted, produce B. burgdorferi s.l. antibodies [26, 96-99]. The results of some studies prove that from an epidemiological point of view, canines should be considered as risk animals because they accompany people in risk-predisposed areas. Additionally, even removing ticks or cleaning infested animals after a walk risks exposure $[9$, 98]. There is a risk of human infection when ticks are crushed during removal from a pet and tick salivary gland material can be exposed to the hands of an owner [9]. However, the same author concluded that infected dogs and cats constitute a minimal threat to people, even though infected ticks can be carried into the domestic habitat [9]. Even though Borrelia can be transmitted from dogs to ticks, dogs are not considered important reservoir hosts $[19,100]$, and some studies examining seropositivity in dogs, their owners and other local residents, found no correlation between dog ownership and infection risk. For example, Goossens et al. [101] did not observe any correlation between the frequency of Borrelia s.l. antibodies in a hunting dog and the serum of the dog's owner. They concluded that direct transfer of ticks between hunters and hunting dogs is insignificant and one's own dog is not an LB hazard.

Numerous studies prove that dogs and cats can be used as sentinels for LB. Serological studies in the USA displayed that exposure of dogs to $B$. burgdorferi reflects the geographical distribution of human LB reports [19], and the use of dog sera to detect and quantify the risk for human LB in a certain region is considered to be more sensitive than the use of incidence reports of human clinical cases [101]. Seroprevalence has been found to be greater in dogs than in humans, due to their greater habitat exposure and greater risk of $B$. burgdorferi infection in dogs than people [102]. The use of dog sera also has the advantage over human serology because the seroprevalence among dogs is more likely to reveal the real environmental risk of $\mathrm{LB}$, due to the short half-life of canine antibodies against B. burgdorferi [101].

The most recent American research carried out by Jones et al. [94] shows that cat and dog pets owners are at increased risk of encountering ticks, and that pet owners are at an increased risk of developing tick-borne disease. They examined whether pet ownership increased the risk for tick encounters and tick-borne disease among residents of 3 Lyme disease-endemic States in the USA as a nested cohort within a randomized controlled test. Pet-owning households had 1.83 times the risk of finding ticks crawling on and 1.49 times the risk of finding ticks attached to household members, compared to people without pets. The authors concluded that pet owners should be attentive of this risk and be reminded to conduct regular tick checks of all household members, including pets,.

Because several authors suggest that the epidemiological profile of borreliosis in dogs is an indicator of the potential risk to people in the area, for that reason the precise mapping of the risk of exposure to LB in frequently visited forests is an important method for targeting prevention and control measures [103]. Moreover, according to the results of a study carried out in the USA by the Center for Disease Control and Prevention (CDC), the more dogs with LB, the higher the frequency of this tick-borne illness in humans. On the basis of data from 'Prevalence Maps' presented by the Companion Animal Parasite Council (www.PetsAndParasites.org), it was established that the humans in areas with a higher than average number of dogs with borreliosis have a greater risk of contracting the disease. It is important to educate pet owners about the risk of tick-borne diseases as well as the need of prevention. Lyme disease research; prevalence maps are crucial implements in the education of humans and veterinary health care professionals and pet owners about this increasing problem. Protecting human and animal health from vector-borne infections requires continuing attention on controlling vector populations, containing the development of novel, practicable strategies that will limit transmission of vector-borne disease pathogens. 


\section{CONCLUSIONS}

1. The 'One health' concept includes the role of small companion animals, specifically for the vector-borne infectious diseases that are shared by humans, dogs and cats.

2. Domestic dogs and cats play a crucial role in the transmission cycles of some tick-borne agents by existence as reservoirs and amplifying hosts - the conditions that the 'One Health' approach requires.

3. From the epidemiological point of view, in the case of humans and domestic animals, urban or peri-urban areas are important with vector ecology playing a very important role in the maintenance of tick populations.

4. Neoehrlichia mikurensis next to Borrelia burgdorferi sensu lato or Anaplasma phagocytophilum, indicating frequent exposure of animals to this potentially pathogenic species, is considered as an emerging tick-borne pathogen in Europe where it is transmitted by I. ricinus.

5. Molecular diagnostics of tick-borne pathogens infections generates a lot of problems, e.g. the choice of molecular methods and molecular markers for the detection of bacterial genomic DNA, but play an important role in the diagnosis of infections.

6. Dogs and cats living in the close vicinity of their owners can act as direct sentinels for the infection of humans. It is believed that the seroprevalence of B. burgdorferi s.l. indicates dogs to be perfect sentinels.

7. Precise mapping of the risk of exposure to Lyme borreliosis in frequently visited forests is an important method for targeting prevention and control measures.

8. Protecting humans and companion animals health from vector-borne infections needs controlling the vector populations, containing development of novel strategies that will limit the risk of transmission of vector-borne pathogens.

\section{REFERENCES}

1. Beugneta F, Marié J-L. Emerging arthropod-borne diseases of companion animals in Europe. Vet Parasitol. 2009; 163(4): 298-305. doi: 10.1016/j.vetpar.2009.03.028. Epub 2009 Mar 26.

2. Otranto D, Dantas-Torres F. Canine and feline vector-borne diseases in Italy: current situation and perspectives. Parasit Vectors 2010; 3: 2. doi: 10.1186/1756-3305-3-2.

3. Skotarczak B. Babesiosis as a disease of people and dogs. Molecular diagnostics: a review. Vet Med. 2008; 53(5): 229-235.

4. Claerebout E, Losson B, Cochez C, Casaert S, Dalemans AC, De Cat A, et al. Ticks and associated pathogens collected from dogs and cats in Belgium. Parasit Vectors 2013; 6: 183. doi: 10.1186/1756-3305-6-183.

5. Maia C, Ramos C, Coimbra M, Bastos F, Martins Â, Pinto P, Nunes M, Vieira ML, Cardoso L, Campino L. Bacterial and protozoal agents of feline vector-borne diseases in domestic and stray cats from southern Portugal. Parasit Vectors 2014; 7: 115. doi: 10.1186/1756-3305-7-115.

6. Maia C, Almeida B, Coimbra M, Fernandes MC, Cristóvão JM, Ramos $\mathrm{C}$, et al. Bacterial and protozoal agents of canine vector-borne diseases in the blood of domestic and stray dogs from southern Portugal. Parasit Vectors 2015; 23(8): 138. doi: 10.1186/s13071-015-0759-8.

7. Little SE. Future challenges for parasitology: Vector control and one health in the Americas. Vet Parasitol. 2013; 195(3-4): 249-255. doi: 10.1016/j.vetpar.2013.04.006.

8. Mencke N. Future challenges for parasitology: Vector control and 'One health' in Europe: The veterinary medicinal view on CVBDs such as tick borreliosis, rickettsiosis and canine leishmaniosis. Vet Parasitol. 2013; 195: 256-271. doi: 10.1016/j.vetpar.2013.04.007. Epub 2013 Apr 6.

9. Day MJ. One health: the importance of companion animal vectorborne diseases. Parasit Vectors 2011; 4: 49. doi: 10.1186/1756-3305-4-49.
10. Kaplan B, Kahn LH, Monath TP, Woodall J. 'One Health' and parasitology. Parasit Vectors 2009; 2: 36. doi: 10.1186/1756-3305-2-36.

11. Brown C. Emerging diseases: the global express. Vet Pathol. 2010; 47: 9-14. Doi: 10.1177/0300985809354351.

12. Rizzoli A, Silaghi C, Obiegala A, Rudolf I, Hubálek Z, Földvári G, et al. Ixodes ricinus and its transmitted pathogens in urban and peri-urban areas in Europe: new hazards and relevance for public health. Front Pub Health 2014; 2: 251. doi: 10.3389/fpubh.2014.00251. eCollection 2014.

13. Kilpatrick AM, Randolph SE. Drivers, dynamics, and control of emerging vector-borne zoonotic diseases. Lancet 2012; 380: 1946-1955. doi: 10.1016/S0140-6736(12)61151-9.

14. Randolph SE. Tick-borne disease systems emerge from the shadows: the beauty lies in molecular detail, the message in epidemiology. Parasitology 2009; 136: 1403-1413. doi: 10.1017/S0031182009005782. Epub 2009 Apr 14.

15. Pfäffle M, Littwin N, Muders SV, Petney TN. The ecology of tick-borne diseases. Int J Parasitol. 2013; 43(12-13): 1059-1077. doi: 10.1016/j. ijpara.2013.06.009. Epub 2013 Aug 1.

16. Wodecka B, Rymaszewska A, Skotarczak B. Host and pathogen DNA identification in blood meals of nymphal Ixodes ricinus ticks from forest parks and rural forests of Poland. Exp Appl Acarol. 2014; 62: 543-555. doi: 10.1007/s10493-013-9763-x. Epub 2013 Dec 19.

17. Ginsberg HS, Faulde MK. Ticks. In: X. Bonnefoy, H. Kampen and K. Sweeney (Eds.), Public Health Significance of Urban Pests. Copenhagen: World Health Organization 2008; pp. 303-345.

18. Król N, Obiegała A, Pfeffer M, Lonc E, Kiewra D. Detection of selected pathogens in ticks collected from cats and dogs in the Wrockaw Agglomeration, South-West Poland. Parasit Vectors 2016; 9(1): 351. doi: 10.1186/s13071-016-1632-0.

19. Little SE, Heise SR, Blagburn BL, Callister SM, Mead PS. Lyme borreliosis in dogs and humans in the USA. Trends Parasitol. 2010; 26(4): 213-218. doi: 10.1016/j.pt.2010.01.006. Epub 2010 Mar 6.

20. Kybicová K, Schánilec P, Hulínská D, Uherková L, Kurzová Z, Spejchalová S. Detection of Anaplasma phagocytophilum and Borrelia burgdorferi sensu lato in dogs in the Czech Republic. Vector Born Zoon Dis. 2009; 9(6): 655-661. doi: 10.1089/vbz.2008.0127.

21. Barth C, Straubinger RK, Sauter-Louis C, Hartmann K. Prevalence of antibodies against Borrelia burgdorferi sensu lato and Anaplasma phagocytophilum and their clinical relevance in dogs in Munich, Germany. Berl. Munch. Tierarztl. Wochenschr. 2012; 125(7-8): 337-344.

22. Ebani VV, Bertelloni F, Torracca B, Cerri D. Serological survey of Borrelia burgdorferi sensu lato, Anaplasma phagocytophilum, and Ehrlichia canis infections in rural and urban dogs in Central Italy. Ann Agric Environ Med. 2014; 21(4): 671-675. doi: 10.5604/12321966.1129912.

23. Skotarczak B, Wodecka B. Molecular evidence of the presence of Borrelia burgdorferi sensu lato in the blood samples taken from dogs in Poland. Ann Agric Environ Med. 2003; 10: 113-115.

24. Skotarczak B, Wodecka B. Identification of Borrelia burgdorferi genospecies inducing Lyme disease in dogs from Poland. Acta Vet Hun. 2005; 53: 12-21.

25. Skotarczak B, Wodecka B, Rymaszewska A, Sawczuk M, Maciejewska A, Adamska M, et al. Prevelance of DNA and antibodies to Borrelia burgdorferi sensu lato in dogs suspected of borreliosis. Ann Agric Environ Med. 2005; 12(2): 199-205.

26. Wodecka B, Rymaszewska A, Sawczuk M, Skotarczak B. Detectability of tick-borne agents DNA in the blood of dogs, undergoing treatment for borreliosis. Ann Agric Environ Med. 2009; 16(1): 9-14.

27. Zygner W, Górski P, Wedrychowicz H. Detection of the DNA of Borrelia afzelii: Anaplasma phagocytophilum and Babesia canis in blood samples from dogs in Warsaw. Vet Rec. 2009; 164: 465-467.

28. Skotarczak B. Methods for parasitic protozoans detection in the environmental samples. Parasite 2009; 16: 183-190.

29. Hovius J, Hovius K, Oei A, Houwers D, Dam A. Antibodies against specific proteins of and immobilizing activity against three strains of Borrelia burgdorferi sensu lato can be found in symptomatic but not in infected asymptomatic dogs. J Clin Microbiol. 2000; 38: 2611-2621.

30. Rauter C, Hartung T. Prevalence of Borrelia burgdorferi sensu lato genospecies in Ixodes ricinus ticks in Europe: a metaanalysis. Appl Environ Microbiol. 2005; 71(11): 7203-7216.

31. Wilhelmsson P, Fryland L, Börjesson S, Nordgren J, Bergström S, Ernerudh J, et al. Prevalence and diversity of Borrelia species in ticks that have bitten humans in Sweden. J Clin Microbiol. 2010; 48(11): 4169-4176. doi: 10.1128/JCM.01061-10. Epub 2010 Sep 15.

32. Nijhof AM, Bodaan C, Postigo M, Nieuwenhuijs H, Opsteegh M, Franssen L, et al. Ticks and associated pathogens collected from domestic animals in the Netherlands. Vector Born Zoon Dis. 2007; 7(4): 585-595. 
33. Kesteman T, Rossi C, Bastien P, Brouillard J, Avesani V, Olive N, et al. Prevalence and genetic heterogeneity of Borrelia burgdorferi sensu lato in Ixodes ticks in Belgium. Acta Clin Belg. 2010; 65(5): 319-322.

34. Reye AL, Hübschen JM, Sausy A, Muller CP. Prevalence and seasonality of tick-borne pathogens in questing Ixodes ricinus ticks from Luxembourg. Appl Environ Microbiol. 2010; 76(9): 2923-2931. doi: 10.1128/AEM.03061-09. Epub 2010 Mar 12.

35. Wodecka B, Skotarczak B. First isolation of Borrelia lusitaniae DNA from Ixodes ricinus ticks in Poland. Scan J Infect Dis. 2005; 1: 1-9.

36. Skotarczak B. Why are there several species of Borrelia burgdorferi sensu lato detected in dogs and humans? Infect Gen Evol. 2014; 23 : 182-188. doi: 10.1016/j.meegid.2014.02.014. Epub 2014 Mar 5.

37. Pangrácová L, Derdáková M, Pekárik L, Hviščová I, Víchová B, Stanko $\mathrm{M}$, et al. Ixodes ricinus abundance and its infection with the tick-borne pathogens in urban and suburban areas of Eastern Slovakia. Parasit Vectors 2013; 6: 238. doi: 10.1186/1756-3305-6-238.

38. Richter D, Matuschka FR. "Candidatus Neoehrlichia mikurensis", Anaplasma phagocytophilum, and Lyme disease spirochetes in questing European vector ticks and in feeding ticks removed from people. J Clin Microbiol 2012; 50: 943-947. doi: 10.1128/JCM.05802-11. Epub 2012 Jan 11.

39. Morganti G, Gavaudan S, Canonico C, Ravagnan S, Olivieri E, Diaferia M, et al. Molecular Survey on Rickettsia spp., Anaplasma phagocytophilum, Borrelia burgdorferi sensu lato, and Babesia spp. in Ixodes ricinus ticks infesting dogs in central Italy. Vector Born Zoon Dis. 2017; 17(11): 743-748. doi: 10.1089/vbz.2017.2154. Epub 2017 Oct 12.

40. Ruiz-Fons F, Fernandez-de-Mera IG, Acevedo P, Gortázar C, de la Fuente J. Factors driving the abundance of Ixodes ricinus ticks and the prevalence of zoonotic, I. ricinus-borne pathogens in natural foci. Appl Environ Microbiol. 2012; 78: 2669-2676. doi: 10.1128/AEM.06564-11. Epub 2012 Jan 27.

41. Zygner W, Jaros S, Wedrychowicz H. Prevalence of Babesia canis, Borrelia afzelii, and Anaplasma phagocytophilum infection in hard ticks removed from dogs in Warsaw (central Poland). Vet Parasitol. 2008; 153: 139-142.

42. Skotarczak B, Rymaszewska A, Wodecka B, Sawczuk M. Molecular evidence of coinfection of Borrelia burgdorferi sensu lato, Human Granulocytic Ehlichiosis Agent, and Babesia microti in ticks from northwestern Poland. J Parasitol. 2003; 89: 194-196.

43. Cisak E, Chmielewska-Badora J, Zwoliński J, Wójcik-Fatla A, Polak J, Dutkiewicz J. Risk of tick-borne bacterial diseases among workers of Roztocze National Park (south-eastern Poland). Ann Agric Environ Med. 2005; 12: 127-132.

44. Zwoliński J, Chmielewska-Badora J, Cisak E, Buczek A, Dutkiewicz J. Prevalence of antibodies to Anaplasma phagocytophilum and Borrelia burgdorferi in forestry workers from the Lublin region. (in Polish). Wiad Parazytol. 2004; 50: 221-227.

45. Skotarczak B, Adamska M, Rymaszewska A, Suproń M, Sawczuk M, Maciejewska A. Anaplasma phagocytophilum and protozoans of Babesia genus in dogs from endemic areas of Lyme disease in northwestern Poland. (in Polish). Wiad Parazytol. 2004; 50: 555-561.

46. Rymaszewska A, Adamska M. Molecular evidence of vector-borne pathogens coinfecting dogs from Poland. Acta Vet Hung. 2011; 59: 215-223. doi: 10.1556/AVet.2011.008.

47. Welc-Faleciak R, Rodo A, Siński E, Bajer A. Babesia canis and other tick-borne infections in dogs in Central Poland. Vet Parasitol. 2009; 166(3-4): 191-198. doi: 10.1016/j.vetpar.2009.09.038. Epub 2009 Sep 26.

48. Alberti A, Zobba R, Chessa B, Addis MF, Sparagano O, Pinna Parpaglia ML, et al. Equine and canine Anaplasma phagocytophilum strains isolated on the island of Sardinia (Italy) are phylogenetically related to pathogenic strains from the United States. Appl Environ Microbiol. 2005; 71: 6418-6422.

49. Ebani V, Cerri D, Fratini F, Ampola M, Andreani E. Seroprevalence of Anaplasma phagocytophilum in domestic and wild animals from central Italy. New Microbiol. 2008; 31: 371-375.

50. Hamel D, Bodarenko A, Silaghi C, Nolte I, Pfister K. Seroprevalence and bacteremia of Anaplasma phagocytophilum in cats from Bavaria and Lower Saxony (Germany). Berl Münch Tierärztl Wochenschr. 2012; 125: 163-167.

51. Alves AS, Milhano N, Santo-Silva M, Santos AS, Vilhena M, De Sousa R. Evidence of Bartonella spp., Rickettsia spp. and Anaplasma phagocytophilum in domestic, shelter and stray cat blood and fleas, Portugal. Clin Microbiol Infect Dis. 2009; 15: 1-3. doi: 10.1111/j.14690691.2008.02636.x. Epub 2009 Mar 26.

52. Krämer F, Schaper R, Schunack B, Połozowski A, Piekarska J, Szwedko A, et al. Serological detection of Anaplasma phagocytophilum, Borrelia burgdorferi sensu lato and Ehrlichia canis antibodies and Dirofilaria immitis antigen in a countrywide survey in dogs in Poland. Parasitol Res. 2014; 113(9): 3229-3239. doi: 10.1007/s00436-014-3985-7. Epub 2014 Jun 29.

53. Welc-Falęciak R, Werszko J, Cydzik K, Bajer A, Michalik J, Behnke JM. Co-infection and genetic diversity of tick-borne pathogens in roe deer from Poland. Vector Born Zoon Dis. 2013; 13: 277-288. doi: 10.1089/ vbz.2012.1136. Epub 2013 Mar 8.

54. Hapunik J, Víchová B, Karbowiak G, Wita I, Bogdaszewski M, Pet'ko B. Wild and farm breeding cervids infections with Anaplasma phagocytophilum. Ann Agric Environ Med. 2011; 18(1): 73-77.

55. Krücken J, Schreiber C, Maaz D, Kohn M, Demeler J, Beck S, et al. A novel high-resolution melt PCR assay discriminates Anaplasma phagocytophilum and "Candidatus Neoehrlichia mikurensis". J Clin Microbiol. 2013; 51: 1958-1961. doi: 10.1128/JCM.00284-13. Epub 2013 Apr 10.

56. Silaghi C, Beck R, Oteo JA, Pfeffer M, Sprong H. Neoehrlichiosis: an emerging tick-borne zoonosis caused by Candidatus Neoehrlichia mikurensis. Exp Appl Acarol. 2015; 68(3): 279-297. doi: 10.1007/s10493015-9935-y. Epub 2015 Jun 17.

57. Grankvist A, Andersson P-O, Mattsson M, Sender M, Vaht K, Höper L et al. Infections with the tick-borne bacterium "Candidatus Neoehrlichia mikurensis" mimic noninfectious conditions in patients with B cell malignancies or autoimmune diseases. Clin Infect Dis. 2014; 58: 1716-1722. doi: 10.1093/cid/ciu189.

58. Heyman P, Cochez C, Hofhuis A, van der Giessen J, Sprong H, Porter SR, et al. A clear and present danger: tick-borne diseases in Europe. Expert Rev Anti Infect Ther. 2010; 8: 33-50. doi: 10.1586/eri.09.118.

59. Michelet L, Delannoy S, Devillers E, Umhang G, Aspan A, Juremalm $\mathrm{M}$, et al. High-throughput screening of tick-borne pathogens in Europe. Front. Cell Infect Microbiol. 2014; 4: 103. doi: 10.3389/ fcimb.2014.00103. eCollection 2014.

60. Diniz PP, Schulz BS, Hartmann K, Breitschwerdt EB. Candidatus Neoehrlichia mikurensis infection in a dog from Germany. J Clin Microbiol. 2011; 49: 2059-2062. doi: 10.1128/JCM.02327-10. Epub 2011 Mar 2.

61. Beck R, Čubrić Čurik V, Račić I, Šprem N, Vujnović A. Identification of Candidatus Neoehrlichia mikurensis and Anaplasma species in wildlife from Croatia. Proceedings of the 1st Conference on Neglected Vectors and Vector-Borne Diseases (EurNegVec) Cluj-Napoca. Parasit Vectors 2014; 7(Suppl 1): O28.

62. Liesner JM, Krücken J, Schaper R, Pachnicke S, Kohn B, Müller E, et al. Vector-borne pathogens in dogs and red foxes from the federal state of Brandenburg, Germany. Vet Parasitol. 2016; 224: 44-51. doi: 10.1016/j.vetpar.2016.05.012. Epub 2016 May 11.

63. Pantchev N, Vrhovec MG, Pluta S, Straubinger RK. Seropositivity of Borrelia burgdorferi in a cohort of symptomatic cats from Europe based on a C6-peptide assay with discussion of implications in disease aetiology. Berl Munch Tierarztl Wochenschr. 2016; 129(7-8): 333-339.

64. Magnarelli LA, Bushmich SL, IJdo JW, Fikrig E. Seroprevalence of antibodies against Borrelia burgdorferi and Anaplasma phagocytophilum in cats. Am J Vet Res. 2005; 66(11): 1895-1899.

65. Pennisi MG, Hofmann-Lehmann R, Radford AD, Tasker S, Belák S, Addie DD, et al. Anaplasma, Ehrlichia and Rickettsia species infections in cats: European guidelines from the ABCD on prevention and management. J Feline Med Surg. 2017; 19(5): 542-548. doi: $10.1177 / 1098612 X 17706462$.

66. Gracia MJ, Marcen JM, Pinal R, Calvete C, Rodes D. Prevalence of Rickettsia and Bartonella species in Spanish cats and their flea. J Vector Ecol. 2015; 40: 233-239. doi: 10.1111/jvec.12159.

67. Leschnik M, Feiler A, Duscher GG, Joachim A. Effect of ownercontrolled acaricidal treatment on tick infestation and immune response to tick-borne pathogens in naturally infested dogs from Eastern Austria Parasit Vectors 2013; 6 (1): 62. doi: 10.1186/17563305-6-62.

68. Littman MP, Goldstein RE, Labato MA, Lappin MR, Moore GE. ACVIM small animal consensus statement on Lyme disease in dogs: diagnosis, treatment, and prevention. J Vet Intern Med. 2006; 20(2): 422-434.

69. De Silva AM, Fikrig E. Borrelia burgdorferi genes selectively expressed in ticks and mammals. Parasitol Today 1997; 13(7): 267-270.

70. Hübner P, Waiblinger HU, Pietsch K, Brodmann P. Validation of PCR methods for quantitation of genetically modified plants in food. J AOAC Int. 2001; 84(6): 1855-1864.

71. Miller JC, von Lackum K, Babb K, McAlister JD, Stevenson B. Temporal analysis of Borrelia burgdorferi Erp protein expression throughout the mammal-tick infectious cycle. Infect Immun. 2003; 71(12): 6943-6952. 
72. Bil-Lula I, Matuszek P, Pfeiffer T, Woźniak M. Lyme Borreliosis - the utility of improved Real-Time PCR Assay in the detection of Borrelia burgdorferi infection. Adv Clin Exp Med. 2015; 24(4): 663-670. doi: $10.17219 /$ acem $/ 28625$

73. Schreiber C, Krücken J, Beck S, Maaz D, Pachnicke S, Krieger K, et al. Pathogens in ticks collected from dogs in Berlin/Brandenburg, Germany. Parasit Vectors 2014; 7: 535. doi: 10.1186/s13071-014-0535-1.

74. Kierwa D, Zaleśny G. Relationship between temporal abundance of ticks and incidence of Lyme borreliosis in Lower Silesia regions of Poland. J Vector Ecol. 2013; 38 (2): 345-352. doi: 10.1111/j.19487134.2013.12050.x.

75. Wodecka B, Leońska A, Skotarczak B. A comparative analysis of molecular markers for the detection and identification of Borrelia spirochetes in Ixodes ricinus. J Med Microbiol. 2010; 59: 309-314. doi: 10.1099/jmm.0.013508-0. Epub 2009 Dec 10.

76. Nunes M, Parreira R, Maia C, Lopes N, Fingerle V, Vieira ML. Molecular identification of Borrelia genus in questing hard ticks from Portugal: Phylogenetic characterization of two novel Relapsing Feverlike Borrelia sp. Infect Genet Evol. 2016; 40: 266-274. doi: 10.1016/j. meegid.2016.03.008. Epub 2016 Mar 11.

77. Wodecka B, Skotarczak B. Differentiation Borrelia species in environmental samples with high-resolution DNA melting analysis. Clin Lab. 2015; 61: 669-676.

78. Dunaj J, Zajkowska JM, Kondrusik M, Gern L, Rais O, Moniuszko A, et al. Borrelia burgdorferi genospecies detection by RLB hybridization in Ixodes ricinus ticks from different sites of North-Eastern Poland Ann Agric Environ Med. 2014; 21(2): 239-243. doi: 10.5604/12321966.1108583

79. Jahfari S, Hofhuis A, Fonville M, van der Giessen J, van Pelt W, Sprong $\mathrm{H}$. Molecular detection of tick-borne pathogens in humans with tick bites and erythema migrans, in the Netherlands. PLoS Negl Trop Dis. 2016; 10(10): e0005042. doi: 10.1371/journal.pntd.0005042. eCollection 2016 Oct.

80. Hamer SA, Tsao JI, Walker ED, Mansfield LS, Foster ES, Hickling GJ. Use of tick surveys and serosurveys to evaluate pet dogs as a sentinel species for emerging Lyme disease. Am J Vet Res. 2009; 70(1): 49-56. doi: 10.2460/ajvr.70.1.49.

81. Cotte V, Bonnet S, Cote M, Vayssier-Taussat M. Prevalence of five pathogenic agents in questing Ixodes ricinus ticks from western France. Vec Born Zoon Dis. 2010; 10: 723-730. doi: 10.1089/vbz.2009.0066. Epub 2009 Dec 18.

82. Cerar T, Ogrinc K, Cimperman J, Lotric-Furlan S, Strle F, RuzićSabljić E. Validation of cultivation and PCR methods for diagnosis of Lyme neuroborreliosis. J Clin Microbiol. 2008; 46(10): 3375-3379. doi: 10.1128/JCM.00410-08. Epub 2008 Aug 20.

83. Elfving K, Lukinius A, Nilsson K. Life cycle, growth characteristics and host cell response of Rickettsia helvetica in a Vero cell line. Exp Appl Acarol. 2012; 56(2): 179-187. doi: 10.1007/s10493-011-9508-7. Epub 2011 Nov 25.

84. Tijsse-Klasen E, Sprong H, Pandak N. Co-infection of Borrelia burgdorferi sensu lato and Rickettsia species in ticks and in an erythema migrans patient. Parasit Vectors 2013; 10(6): 347. doi: 10.1186/17563305-6-347.

85. Koetsveld J, Tijsse-Klasen E, Herremans T, Hovius JW, Sprong H. Serological and molecular evidence for spotted fever group Rickettsia and Borrelia burgdorferi sensu lato co-infections in The Netherlands. Ticks Tick-Borne Dis. 2016; 7(2): 371-377. doi: 10.1016/j. ttbdis.2015.12.010. Epub 2015 Dec 17.

86. Summers BA, Straubinger AF, Jacobson RH, Chang YF, Appel MJ, Straubinger RK. Histopathological studies of experimental lyme disease in the dog. J Comp Pathol. 2005; 133: 1-13.
87. Gerber B, Eichenberger S, Haug K, Wittenbrink MM. The dilemma with Lyme borreliosis in the dog with particular consideration of "Lyme nephritis". Schweiz Arch Tierheilkd. 2009; 151 (10): 479-483. doi: 10.1024/0036-7281.151.10.479.

88. Wölfel R, Essbauer S, Dobler G. Diagnostics of tick-borne rickettsioses in Germany: A modern concept for a neglected disease. Int J Med Microbiol. 2008; 298: 368-374.

89. Skotarczak B, Wodecka B, Rymaszewska A, Adamska M. Molecular evidence for bacterial pathogens in Ixodes ricinus ticks infesting Shetland ponies. Exp Appl Acarol 2016; 69(2): 179-189. doi: 10.1007/ s10493-016-0027-4. Epub 2016 Feb 26.

90. Courtney JW, Kostelnik LM, Zeidner NS, Massung RF. Multiplex realtime PCR for detection of Anaplasma phagocytophilum and Borrelia burgdorferi. J Clin Microbiol. 2004; 42: 3164-3168.

91. Jahfari S, Fonville M, Hengeveld P, Reusken C, Scholte EJ, Takken W, Heyman P, Medlock J, Heylen D, Kleve J, Sprong H. Prevalence of Neoehrlichia mikurensis in ticks and rodents from north-west Europe. Parasit Vectors. 2012; 5: 74. doi: 10.1186/1756-3305-5-74.

92. Silaghi C, Woll D, Mahling M, Pfister K, Pfeffer M. Candidatus Neoehrlichia mikurensis in rodents in an area with sympatric existence of the hard ticks Ixodes ricinus and Dermacentor reticulatus. Parasit Vectors. 2012; 5: 285. doi: 10.1186/1756-3305-5-285.

93. Skotarczak B. Canine borreliosis-epidemiology and diagnostics. Ann Agric Environ Med. 2002; 9: 137-140.

94. Jones EH, Hinckley AF, Hook SA, Meek JI, Backenson B, Kugeler KJ, Feldman KA. Pet ownership increases human risk of encountering ticks. Zoon Pub Health 2017; doi: 10.1111/zph.12369.

95. Guerra M, Walker E, Kitron U. Canine surveillance system for Lyme borreliosis in Wisconsin and northern Illinois: geographic distribution and risk factor analysis. Am J Trop Med Hyg. 2001; 65: 546-552.

96. Magnarelli LA, Anderson JF, Johnson RC. Analyses of mammalian sera in enzyme-linked immunosorbend assay with different strains of Borrelia burgdorferi sensu lato. J Wild Dis 1995; 31: 159-165.

97. Magnarelli LA, Ijdo JW, Padula SJ, Flavell RA, Fikrig E. Serologic diagnosis of Lyme borreliosis by using enzyme-linked immunosorbent assays with recombinant antigens. J Clin Microbiol. 2000; 38: 17351739 .

98. Stefancikova A, Tresova G, Petko B, Skardova I, Sesztakova E. ELISA comparison of theree whole-cell antigens of Borrelia burgdorferi sensu lato in serological study of dogs from area of Kosice, eastern Slovakia. Ann Agric Environ Med. 1998; 5, 25-30.

99. Straubinger RK, Straubinger AF, Harter L, Jacobson RH, Chang YF, Summers BA, et al. Borrelia burgdorferi migrates into joint capsules and causes an up-regulation of interleukin- 8 in synovial membranes of dogs experimentally infected with ticks. Infect Immun. 1997; 65: 1273-1285.

100. Skotarczak B, Adamska M, Sawczuk M, Maciejewska A, Wodecka B, Rymaszewska A. Coexistence of tick-borne pathogens in game animals and ticks in western Poland. Vet Med. 2008; 53: 668-675.

101. Goossens HAT, Van Den Bogaard AE, Nohlmans MKE. Dogs as sentinels for human Lyme borreliosis in The Netherlands. J Clin Microbiol. 2001; 39: 844-848.

102.Eng TR, Wilson ML, Spielman A, Lastavica CC. Greater risk of Borrelia burgdorferi infection in dogs than in people. J Infect Dis. 1988; 158: 1410-1411.

103. Vourc'h G, Abrial D, Bord S, Jacquot M, Masséglia S, Poux V, et al. Mapping human risk of infection with Borrelia burgdorferi sensu lato, the agent of Lyme borreliosis, in a periurban forest in France. Ticks Tick-Born Dis. 2016; 7(5): 644-652. doi: 10.1016/j.ttbdis.2016.02.008. Epub 2016 Feb 6. 